upperside joins the brown, is a horizontal row of curved brown lines; the outer margin of anterior wings and of the posterior wings as far as the tail is brown.

Expanse of wings $1 \frac{1}{2}$ inch.

The underside resembles Logania sriva and malayica of Distant, both of which species have lately been received by me from North Borneo; but the length of the antennæ and shape of the anterior wings of caudatus, irrespective of the neuration, preclude its being placed in that genus.

\title{
IX.-Note on the Capture of a Freshwater Eel in a Ripe
} Condition. By W. L. Calderwood.

A FEMALE eel (Anguilla vulgaris), measuring $29 \frac{1}{2}$ inches in length, was captured on the 27 th of December last. The capture was of some interest because the female was almost ready to spawn and was found about twelve miles south of the Eddystone, $i . e$. twenty miles from Rame Head, the nearest point of land. That a freshwater eel should be found so far out at sea, at the breeding-season, is not in itself very surprising, because it has long been conjectured that Anguilla spawns in salt water; but in the present state of knowledge any of the rare instances of the actual capture of a specimen in the condition of sexual maturity should be recorded.

The ovaries were pure white in colour, and corresponded exactly in appearance with those described and figured by Broek in 1881\%. They extended the entire length of the abdominal cavity, showed no signs of any blood-supply, and when touched crumbled away most easily. The ova were apparently quite ready to drop from the outer surfaces of the organs. Sections showed, however, that in each ripening ovum the nuclear membrane was still distinctly visible. The nucleoli of largest size were arranged round the periphery, smaller bodies being found amongst the granular protoplasm of the nucleus. The substance of the ovum itself was richly stored with oil-globules, giving the characteristic appearance known in the conger's egg $\dagger$.

* Broek, "Untersuchungen über die Geschlechtsorgane einiger Muraenoiden," Mitt. zool. Stat. Neapel, Band ii. p. 415.

$\dagger$ Calderwood, "A Contribution to our Knowledge of the Ovary and Intraovarian Eggs of Teleosts," Journ. Mar. Biol. Assoc. vol. ii. no. 4, pl. xi. 


\section{$2 \mathrm{BHL}$ Biodiversity Heritage Library}

Calderwood, W. L. 1893. "IX.-Note on the capture of a freshwater eel in a ripe condition." The Annals and magazine of natural history; zoology, botany, and geology 12, 35-35. https://doi.org/10.1080/00222939308677572.

View This Item Online: https://www.biodiversitylibrary.org/item/78509

DOI: https://doi.org/10.1080/00222939308677572

Permalink: https://www.biodiversitylibrary.org/partpdf/62258

\section{Holding Institution}

University of Toronto - Gerstein Science Information Centre

\section{Sponsored by}

University of Toronto

\section{Copyright \& Reuse}

Copyright Status: NOT_IN_COPYRIGHT

This document was created from content at the Biodiversity Heritage Library, the world's largest open access digital library for biodiversity literature and archives. Visit BHL at https://www.biodiversitylibrary.org. 